\title{
Genetic diversity and morphological responses of Capsicum annuum varieties under aluminum stress
}

\author{
ANDRIYANI ${ }^{1}$, NURUL JADID ${ }^{1, \boldsymbol{v}}$ \\ ${ }^{1}$ Department of Biology, Faculty of Sciences and Data Analytics, Institut Teknologi Sepuluh Nopember. Jl. Arief Rahman Hakim-Surabaya, East Java, \\ Indonesia. Tel./fax. +62-31-5963857, ^email: nuruljadid@bio.its.ac.id \\ Manuscript received: 21 February 2021. Revision accepted: 16 April 2021.
}

\begin{abstract}
Andriyani, Jadid N. 2021. Genetic diversity and morphological responses of Capsicum annuum varieties under aluminum stress. Biodiversitas 22: 2576-2582. Capsicum annuum is one of the most cultivated vegetable crops in the world. Its fruit contains various beneficial metabolites which possess antioxidant activities. Fertilizers play important role to increase plant productivity. However, excessive use of fertilizers could harm the environment. Heavy metals, including aluminum ( $\mathrm{Al}$ ), contamination have been reported to negatively affect plant production and inhibit root growth. $C$. annuum var Ciko, Lingga, Lembang1, and Tanjung2 are commonly cultivated in Indonesia. However, the genetic diversity of those plants and their responses to Al stress condition are still unknown. Therefore, our study aimed to analyze the genetic diversity of four C. annuum cultivars and to observe their morphological responses under Al stress conditions. The genetic diversity was analyzed using five universal inter-simple sequence repeat (ISSR) primers. Our results showed that the PIC values ranged from 0 (primer 825) to 0.6375 (Primer 9). The UPGMA phylogenetic construction also demonstrated that the cv. Lembang1 is closely related to the cv Lingga. Meanwhile, cv Tanjung 2 is closely related to the cv. Ciko. Each cultivar also performed different morphological responses under Al stress conditions. Our data showed that $\mathrm{Al}$ affected significantly root growth but not affected their plant height. Aluminum at $100 \mathrm{ppm}$ significantly decreased root length of cv. Lingga.
\end{abstract}

Keywords: Aluminium, C. апnuum, genetic diversity, ISSR, morphological responses.

\section{INTRODUCTION}

Capsicum (Capsicum annuum) is a horticultural crop that possesses high economic value (Rukmana 1995). It is consumed worldwide and used in some industrial domains, including food and health industries (Khan and Leskovar 2006). This plant is widely used in the food industry because of its alkaloid content, namely capsaicin, which is responsible for its spicy taste (Hoffman et al. 1983). In addition, Capsicum is also a source of vitamin $\mathrm{C}$ and vitamin B (Ganguly 2017). Moreover, this crop contains valuable essential oil, capsitol. Capsitol is used to substitute the eucalyptus oil to reduce stiff shortness of breath, itching, and rheumatism. The flavonoid content of this crop is also useful to inhibit inflammation (Rukmana 2002). Due to the high utilization of capsicum plants, generation of new varieties with elite phenotypes becomes important Some of the varieties that are currently developed in Indonesia include var. Ciko, Tanjung 2, Lingga and Lembang 1. These four varieties have different productivity. For instance, var. Ciko has a productivity of 13.4-20.5 $\mathrm{t} \mathrm{ha}^{-1}$, and that of Lembang1 is 15.6-19 $\mathrm{t} \mathrm{ha}^{-1}$, Lingga is 13.4-20.5 $\mathrm{tha}^{-1}$, and Tanjung2 is $12 \mathrm{t} \mathrm{ha}^{-1}$ (Balitsa 2018). Although there are many varieties of Capsicum plants that are being cultivated in Indonesia, their genetic information is still limited. Therefore, conducting genetic diversity analysis of important crops is necessary for the development of new variety and conserving the genetic resources (Sun et al. 2008). The study of genetic diversity can be done using many molecular markers.
Molecular markers have been widely used to study the genetic variations among genotypes (Kaur et al. 2015), population studies ( $\mathrm{Ng}$ et al. 2015), phylogeny (Acharya et al. 2004), and genetic mapping (Yagi et al. 2017). Currently, many molecular markers have been developed including Amplified polymorphic length (AFLP), Restriction fragment length polymorphism (RFLP), and Simple sequence repeat (SSR), Random amplified polymorphic DNA (RAPD), and inter simple sequence repeat (ISSR) (Nadeem et al. 2017). ISSR is a highly polymorphic marker that has been used for genetic diversity studies (Xing et al. 2015). This marker is costeffective, high productivity, and is not affected by environmental factors (Das et al. 2017; Ray et al. 2019).

Genetic diversity is one reason for the different responses of plants to environmental conditions (Rukmana 2005). Environmental conditions are a determining factor for the productivity level of chili plants. Indonesia is a tropical country where most of the land is acidic, 148 million hectares are considered as dryland, and 102.8 million hectares are acidic dryland (Mulyani et al. 2004). Acidic soil is defined as soil where its top layer possesses $\mathrm{pH}$ of less than 5.5 (He et al. 2019). Unpredictable climate change and relatively high rainfall in most Indonesian regions have resulted in an intensive level of alkaline soil leaching. It leads to an increase in soil acidity (Subagyo et al. 1998).

Aluminum ( $\mathrm{Al})$ is a heavy metal that can disturb plants in the form of trivalent cations $\left(\mathrm{Al}^{3+}\right)$. Al quickly binds to the apoplast and it is also deposited in the plant vacuole. High $\mathrm{Al}$ accumulation will trigger the production of free 
radicals in plants. The reactive oxygen species (ROS) will initiate the lipid peroxidation of the cell membranes (Panda and Baluska 2015). Al also interferes with the absorption of nutrients from soils (Moustaka et al. 2016). In acidic soil, free aluminum forms insoluble aluminum phosphate which causes a phosphate deficiency (Handayanto 2017). $\mathrm{Al}^{3+}$ will bind to the $\mathrm{H}_{2} \mathrm{PO}_{4}$-anions and precipitate them as $\mathrm{Al}-$ phosphate (Raharjo et al. 2007).

Several studies have shown that Al stress influences plant physiology, morphology and molecular aspects. Karimaei and Poozesh (2016) revealed that Al stress reduced the chlorophyll content in Spinacia oleracea, affecting the photosynthesis process. Heavy metals can induce damage that can inhibit the photosynthesis process (Jadid et al. 2017). The photosynthetic process can be inhibited because heavy metals replace $\mathrm{Mg}^{2+}$ in chlorophyll molecules (Kuepper et al. 1998). Heavy metals can also replace enzyme cofactors, thereby reducing the activity of photosynthetic enzymes (Shanmugam et al. 2012). High accumulation of aluminum stress in Stenocalyx dysentericus was reported to cause root growth inhibition (Rodrigues et al. 2016). Another study has demonstrated an increase in proline synthesis during $\mathrm{Al}$ stress (Mantovanini et al. 2019). In addition, like in other abiotic stress conditions, plants regulate their responses through a dynamic gene expression (Jadid et al. 2018). Based on the above background, this study evaluated the genetic diversity of four varieties of capsicum using ISSR markers and the morphological responses of four varieties of capsicum during $\mathrm{Al}$ stress conditions.

\section{MATERIALS AND METHODS}

\section{Study area}

Capsicum cultivation and $\mathrm{Al}$ stress condition were conducted at the greenhouse facility of the Urban Farming area of the Institut Teknologi Sepuluh Nopember, Surabaya, Indonesia. Meanwhile, the morphological responses of capsicum against $\mathrm{Al}$ stress were evaluated at the Laboratory of Bioscience and Plant Technology, Department of Biology, Institut Teknologi Sepuluh Nopember, Surabaya, Indonesia.

\section{Procedures}

\section{Plant materials, cultivation and Al stress condition}

Four capsicum varieties were used in this study. It includes capsicum var. ciko, lembangl, lingga and tanjung2. The seeds were soaked using tap water overnight. Subsequently, the seeds were germinated in the polybags containing soil and compost media with a ratio of 1: 1 according to the method described previously (Jadid et al. 2017; Setiadi 2006).

The soil media for $\mathrm{Al}$ stress treatment was dried for 24 hours and then put in a $15 \mathrm{~cm} \times 15 \mathrm{~cm}$ polybag (Dogic et al. 2017). Al stress treatment was carried out after the plants aged 2 weeks. Before mixing $\mathrm{Al}$ into the soil, a stock of $1 \mathrm{~L} \mathrm{AlCl}_{3} 1000 \mathrm{ppm}$ was made. The $\mathrm{Al}$ concentrations used were 0, 100, 200 and $300 \mathrm{ppm}$. The $1000 \mathrm{ppm} \mathrm{AlCl}_{3}$ stock was then diluted to make 100, 200 and $300 \mathrm{ppm}$ of $\mathrm{Al}$ solution. The $\mathrm{pH}$ was set at 5.5 for $0 \mathrm{ppm}$ (control) and \pm 3.5 for Al-treated soils. The Al solutions were applied every day in the morning with a volume of $30 \mathrm{ml}$ per polybag for 32 days (Supena et al. 2014).

\section{Genomic DNA extraction, quantification and quality measurement}

Total genomic DNA was obtained from each capsicum variety. Leaves of each capsicum variety were used to extract the genomic DNA (Jadid et al. 2016). The extraction was carried out using Geneaid ${ }^{\circledR}$ DNA Mini Kit according to the protocols provided by the manufacturer. The quantity and quality of total genomic DNA were determined using NanoDrop (Thermo Scientific ${ }^{\mathrm{TM}}$ nanodrop 2000). The concentration of the DNA extract was expressed as $n g \mathrm{l}^{-1}$, meanwhile, the quality of the genomic DNA extract was evaluated based on the A260/A280. Good quality of DNA extract ranges from 1.8-2.0 (Animasun et al. 2015; Jadid et al. 2018).

\section{DNA amplification using ISSR markers}

Genomic DNA obtained previously was used as template for DNA amplification using ISSR markers. A total of 5 ISSR primers were used in this study. These primers were synthesized by the IDT Integrated DNA Technologies. They were ISO2, Primer 5, Primer 9, ISSR825, and ISSR-811 (Table 1) (Olatunji et al. 2015; Rana et al. 2013; Ibarra-Torres et al. 2015). PCR amplifications were conducted in a final volume of reaction $25 \mu \mathrm{l}$ using GoTaq $^{\circledR}$ Green Master Mix (Promega, USA). The DNA amplification program consisted of initial denaturation 95 ${ }^{\circ} \mathrm{C}$ for $2 \mathrm{~min}$, followed by 35 cycles of denaturation at 95 ${ }^{\circ} \mathrm{C}$ for $30 \mathrm{~s}$, annealing at primer specific temperature for 30 $\mathrm{s}$, and extension at $72^{\circ} \mathrm{C}$ for $1 \mathrm{~min}$. Final extension was done at $72{ }^{\circ} \mathrm{C}$ for $5 \mathrm{~min}$. The amplicons produced by PCR amplification using ISSR primers were then separated by electrophoresis at 100 volts on $2 \%$ gel agarose containing 1 $\mu \mathrm{l}$ ethidium bromide in $0.5 \mathrm{x}$ tris-boric acid EDTA buffer. Subsequently, the gel was visualized under UV transilluminator.

Table 1. Characteristics of the ISSR primers used for genotyping analysis of Capsicum varieties.

\begin{tabular}{lllc}
\hline Primer & Short sequence & Extended sequence $\left(\mathbf{5}^{\prime} \rightarrow \mathbf{3}^{\prime}\right) \boldsymbol{Y}=(\mathbf{C}, \mathbf{T})$ & Number of bases \\
\hline ISO 2 & $(\mathrm{AC})_{8}$ YG & ACACACACACACACACYG & 19 \\
Primer 5 & $(\mathrm{GA})_{7}$ GC & GAGAGAGAGAGAGAGC & 16 \\
Primer 9 & $(\mathrm{AG})_{10} \mathrm{~T}$ & AGAGAGAGAGAGAGAGAGAGT & 21 \\
ISSR-825 & $(\mathrm{AC})_{8} \mathrm{~T}$ & ACACACACACACACACT & 17 \\
ISSR-811 & $(\mathrm{CAC})_{2}(\mathrm{AC})_{4}$ AAT & CACCACACACACACAAT & 17 \\
\hline
\end{tabular}




\section{Data analysis}

The study was conducted with a completely randomized design (CRD) factorial of two factors, the concentration of aluminum and plant varieties. Two morphological characters were measured in this study. It includes plant height and root length of each Capsicum variety. These parameters were analyzed using two-way Analysis of Variance (ANOVA) with a 95\% confidence level.

The results of the PCR amplifications through gel electrophoresis were analyzed. Each ISSR band formed represented as independent locus and were scored as present (1) and absent (0). These data were then evaluated as a binary data matrix. The presence of monomorphic and polymorphic bands was determined. The percentage of polymorphism was calculated to measure the percentage of polymorphic alleles per primer used in this study (Monfared et al. 2018). The measurement was calculated using the following equation:

Percentage of polymorphism $=\frac{\text { Number of polymorphic allele }}{\text { Total alleles }} \times 100 \%$

The polymorphism information content (PIC) was evaluated using the following formula:

$$
\mathrm{PIC}=2 \mathrm{Pi}(1-\mathrm{Pi})
$$

Where: $\mathrm{Pi}$ is the frequency of the presence of polymorphic bands in different ISSR primers. The calculation was done using Gen Calc software (https://gene-calc.pl/). Clustering was performed using UPGMA (Unweighted Pair Group Method using Arithmetic average) algorithm through the MVSP (MultiVariate Statistical Package). The PIC was used to evaluate the genetic markers. Therefore, the PIC value was classified into three classes, including high informative marker $(P I C>0.60)$; moderate informative primer $(0.3$ $<P I C<0.59)$; less informative primer $(P I C<0.3)$ (Mateescu et al. 2005).

\section{RESULTS AND DISCUSSION}

\section{ISSR analysis}

ISSR analysis is a PCR-based technique used for evaluating genetic variability. Therefore, good quality DNA genomic (gDNA) extract is required. The results of the gDNA extraction from the four capsicum varieties are presented in table 2 . The amount of the gDNA ranged from

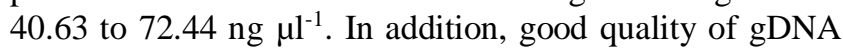
was also obtained, according to the A260/A280 ratio, which ranged from 2.08 to 2.19 (Table 2). This was also reflected by clear and reproducible amplification profile (Figure 1). The quality of DNA extract influences DNA amplification. The absorbance ratio 260/280, ranging from 1.8 to 2.0 is commonly used to measure the quality of the DNA. The optical density at that range indicates that the DNA is free from protein and RNA contamination (Qamar et al. 2017).

After the good quality of gDNA was obtained, the four Capsicum varieties were evaluated using ISSR markers. In this recent study, genetic variation of four varieties of $C$. annuum var. ciko, tanjung2, lembangl, and lingga was evaluated using 5 ISSR primers, namely ISO2, PRIMER 5, PRIMER 9, ISSR-825, and ISSR 811 (Table 1). Some previous studies have reported the effectiveness of ISSR PCR-based method to demonstrate genetic variability among Capsicum species (Ibarra-Torres et al. 2014; Olatunji et al. 2019; Rana et al. 2014). A total of 108 bands were produced. They ranged from 200-1,700 bp (Figure 1). We obtained a total of 25 polymorphic bands.

Table 2. Concentration of the gDNA extracted from four Capsicum varieties

\begin{tabular}{lll}
\hline Capsicum varieties & $\begin{array}{l}\text { gDNA } \\
\text { (ng/ } \mathbf{\mu l})\end{array}$ & OD 260/280nm \\
\hline Capsicum annuum var. tanjung2 & 43.40 & 2.19 \\
Capsicum annuum var. ciko & 40.63 & 2.10 \\
Capsicum anпиum var lembang1 & 72.44 & 2.08 \\
Capsicum annuum var lingga & 42.43 & 2.19 \\
\hline
\end{tabular}
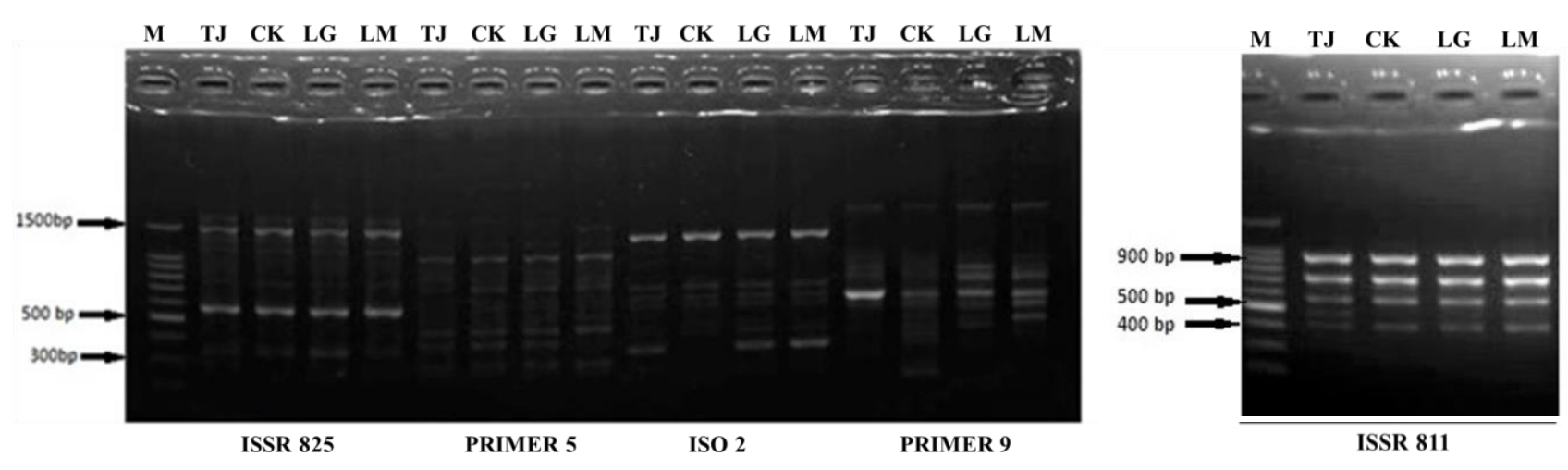

Figure 1. PCR-amplified ISSR pattern of four Capsicum varieties on $2 \%$ agarose gel using five marker primers. M, molecular marker; TJ, Capsicum var. tanjung2; CK, Capsicum var. Ciko; LG, Capsicum var. lingga; LM, Capsicum var. lembang1. 
Inter-simple sequence repeats (ISSR) molecular marker is one of the DNA markers, which uses the microsatellite regions in the genome for direct DNA amplifications (Mehrotra and Goyal 2014). These markers allow us to provide the genetic information of many loci. Therefore, it can be used to monitor the genetic variability among species or interspecies populations (Sudupak 2004). Genetic diversity and genetic relatedness analysis are indispensable for crop improvement (Igwe et al. 2017). The average number of polymorphic bands and percent of polymorphism were 5 and $35.75 \%$, respectively. Highest percentage of polymorphism $(70 \%)$ was obtained by primer 9 with a total of 8 polymorphic bands, followed by primer $5(55.56 \%)$, ISO 2 primer (33.3\%), and ISSR-811 (20\%). We observed no polymorphic bands in ISSR-825 (Table 3). The average percentage of polymorphism is relatively moderate. Our results are in contrast with previous study, which observed relatively low genetic diversity among other Capsicum varieties (Olatunji and Afolayan 2019). Our results suggest that Capsicum varieties from Indonesia might possess different genetic profile than others Capsicum varieties around the world.

The efficacy of the ISSR markers used in this study was quantified by PIC, which varied from 0 to 0.64 . The average PIC value in this study was 0.29 (PIC>0.20). This indicates their effectiveness (Mandal et al. 2013). According to Mateescu et al. (2005), the PIC value is divided into three classes, high informative marker $(P I C>$ $0.60)$; moderate informative primer $(0.3<P I C<0.59)$; less informative primer $(P I C<0.3)$. Highest PIC value was demonstrated by primer $9(0.64)$, followed by primer 5 (0.39), ISSR-811 (0.19) and ISO 2 (0.15). Meanwhile, the minimum PIC value was showed by ISSR-825. Therefore, primer 9 is classified as highly informative marker and primer 3 as moderate informative marker. This is in line with previous study which stated that primer 9 is high informative marker to demonstrate the genetic variability among Capsicum (Olatunji and Afolayan 2019). This also indicates that primer 9 is important marker for linkage analysis (Hildebrand et al. 1992). Other ISSR markers used in this study were less informative.

\section{Cluster analysis}

Data from DNA amplification was scored and used subsequently to construct a dendrogram using UPGMA analysis to cluster the Capsicum varieties cluster. UPGM dendrogram was constructed based on the genetic similarity among plant species according to the molecular marker used (Dikshita and Sivarajb 2015). Our results showed that four Capsicum varieties were clustered into two major groups. Cluster 1 consisted of $C$. annuum var. lembangl and var. lingga at 0.5 similarity level. Whereas, the second group consisted of $C$. annuum var. ciko and var. tanjung 2 at similarity level of 0.6 (Figure 2).

\section{Morphological responses of Capsicum varieties against $A l$ stress}

Observation of the morphological responses of $C$. аппиит varieties against $\mathrm{Al}$ stress was carried out after 32 days of aluminum stress treatment (Figure 3). Our data showed that $\mathrm{Al}$ stress inhibited Capsicum growth. We observed that plant height of all Capsicum varieties tested in this study was reduced following an increase of Al stress level (Figure 4). C. annuum var. ciko exhibited the greatest reduction of plant height among the varieties. This is in line with previous study conducted by Won et al. (2013) which stated that giving heavy metal $\mathrm{Al}$ can reduce plant height. The higher the Al stress concentration given, the higher the plant height is inhibited.

The statistical analysis showed that the interaction between $\mathrm{Al}$ concentration and Capsicum varieties was not significantly influencing the plant height ( $\mathrm{p}$ value $>0.05$ ). However, we observed different levels of plant reduction among the tested Capsicum varieties. Capsicum var. ciko exhibited highest reduction of plant height compared to the control plants. They demonstrated $14.7 \%, 28 \%$ and $17.1 \%$ of plant height reduction compared to control after being treated with 100, 200 and $300 \mathrm{ppm}$ of $\mathrm{Al}$, respectively. It was followed by Capsicum var. lembang1, which performed $8.8 \%, 23.01 \%$ and $17.6 \%$ of plant height reduction compared to control after being treated with 100 , 200, and $300 \mathrm{ppm}$ of $\mathrm{Al}$, respectively. Meanwhile, Capsicum var. tanjung2 exhibited lowest plant height reduction compared to the control plant after $\mathrm{Al}$ treatment (Figure 4).

Table 3. Total number of amplified fragments and polymorphic information generated by five ISSR primers in four Capsicum varieties.

\begin{tabular}{|c|c|c|c|c|c|c|c|}
\hline Primer & $\operatorname{Tm}\left({ }^{0} \mathrm{C}\right)$ & TL & $\mathbf{L P}$ & TNB & NP & $\% \mathrm{P}$ & PIC \\
\hline ISO 2 & 54.3 & 6 & 2 & 22 & 6 & 33.3 & 0.15 \\
\hline Primer 5 & 47.0 & 9 & 5 & 25 & 10 & 55.56 & 0.39 \\
\hline Primer 9 & 52.8 & 10 & 7 & 20 & 8 & 70 & 0.64 \\
\hline ISSR-825 & 51.4 & 6 & 0 & 24 & 0 & 0 & 0 \\
\hline ISSR-811 & 52 & 5 & 1 & 17 & 1 & 20 & 0.19 \\
\hline Total & & 36 & 15 & 108 & 25 & & \\
\hline Mean & & 7 & 3 & 20.8 & 5 & 35.77 & 0.29 \\
\hline
\end{tabular}

Note: Tm $\left({ }^{\circ} \mathrm{C}\right)$-Annealing temperature; TL-total loci; LP-polymorphic loci; \%P-percentage polymorphism; NB-total number of bands; NP-total number of polymorphic band; PIC-polymorphic information content. 
Aluminum accumulation had been reported to reduce the adsorption rate of water and nutrient, including phosphate from soils through plant root (Karimaei et al. 2016). $\mathrm{Al}^{3+}$ will bind the $\mathrm{H}_{2} \mathrm{PO}_{4}{ }^{-}$anion and precipitate it as an $\mathrm{Al}$-phosphate reaction through the $\mathrm{H}_{2} \mathrm{PO}_{4}^{-}+2 \mathrm{OH}_{2}^{-}+\mathrm{Al}_{3}$ $+->\mathrm{Al}(\mathrm{OH}) 2 \mathrm{H}_{2} \mathrm{PO}_{4}$ reaction. This causes phosphate deficiency because plants always absorb phosphate as $\mathrm{H}_{2} \mathrm{PO}_{4}^{-}, \mathrm{HPO}_{4}{ }^{2-}$ and $\mathrm{PO}_{4}{ }^{3-}$ which are mainly available in the soil. (Raharjo et al. 2007). In addition, a decrease in potassium and calcium nutrients was also observed in wheat that was exposed to aluminum $(\mathrm{Al})$ stress $(\mathrm{Oh}$ et al. 2013). Calcium (Ca) is a component of plant cell walls and regulates plant cell wall construction while plants use potassium $(\mathrm{K})$ to activate enzymes, photosynthesis, protein formation and sugar transport (McCauley 2011).

Our observation also showed that $\mathrm{Al}$ stress treatment also interfered root growth. Statistical data analysis showed that interaction between Capsicum varieties and $\mathrm{Al}$ concentration was significantly influenced root length ( $p$ value $<0.05$ ). The lowest average length of the main root was demonstrated in $C$. аnnuum var. lingga which $\mathrm{Al}$ stresses at a concentration of $100 \mathrm{ppm}$. Meanwhile, $C$. annuum var. lembangl showed a decrease in root length after being treated with Al stress at 100 and 300 ppm. Finally, var. ciko exhibited root growth inhibition when they were exposed to $\mathrm{Al}$ stress at 200 and 300 ppm (Table 4).

UPGMA

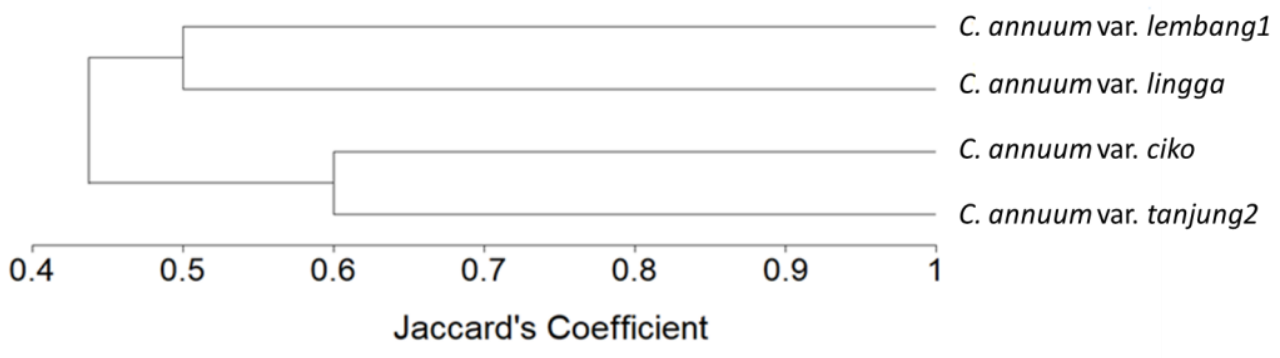

Figure 2. ISSR-based dendrogram of genetic similarity among Capsicum varieties.

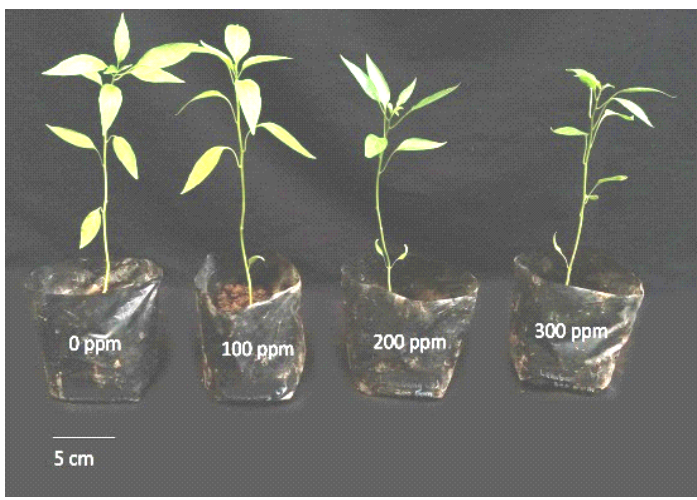

A

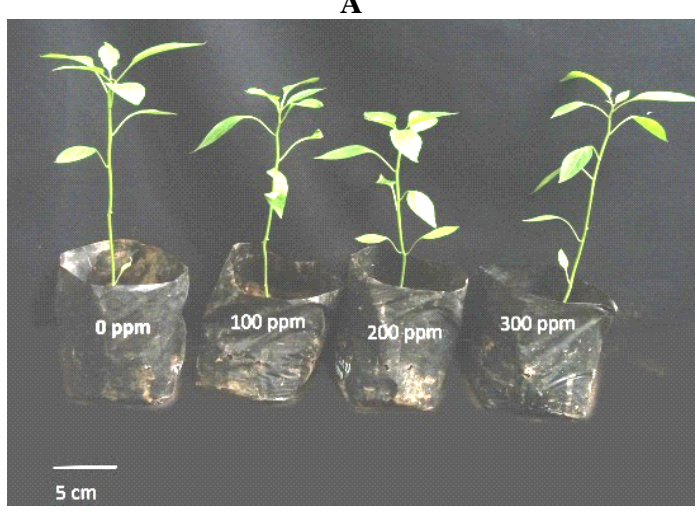

C

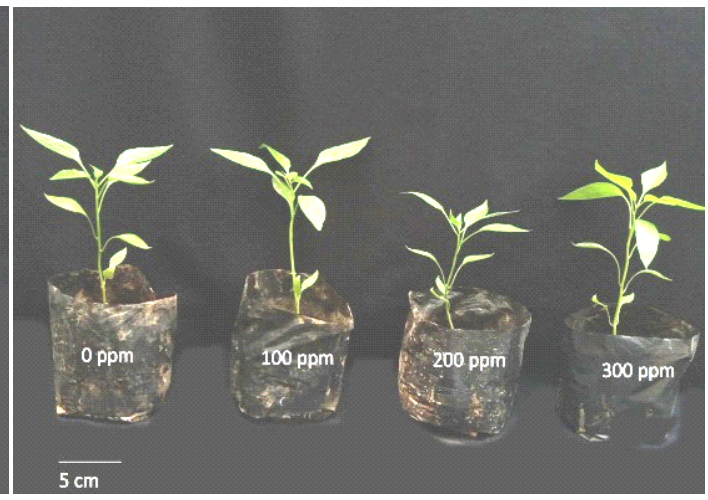

$\mathbf{B}$

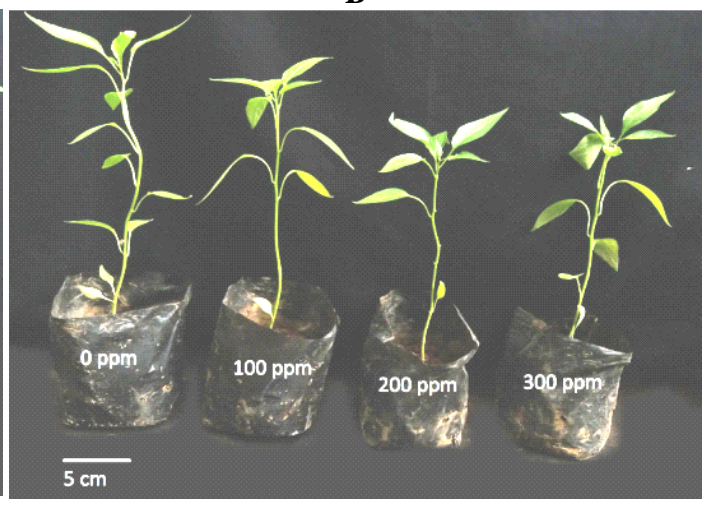

D

Figure 3. Observation of morphological responses of Capsicum varieties against Al stress treatment at 73 days after planting (DAP). A. Capsicum annum var. lembang1, B. Capsicum annum var. ciko, C. Capsicum annum var. tanjung2, D. Capsicum annum var. lingga 
Table 4. Response of Capsicum varieties on root growth under Al stress treatment at 73 days after planting (DAP).

\begin{tabular}{lcccc}
\hline $\begin{array}{l}\text { Al conc. } \\
\text { (ppm) }\end{array}$ & \multicolumn{4}{c}{ Root length (cm) } \\
\cline { 2 - 5 } & Lingga & Lembang1 & Tanjung2 & Ciko \\
\hline 0 & $3.46 \pm 1.03^{\mathrm{ab}}$ & $2.34 \pm 0.23^{\mathrm{bc}}$ & $2.36 \pm 0.13^{\mathrm{bc}}$ & $1.8 \pm 0.57^{\mathrm{c}}$ \\
100 & $1.6 \pm 0.38^{\mathrm{c}}$ & $2.3 \pm 0.63^{\mathrm{abc}}$ & $2.62 \pm 0.4^{\mathrm{abc}}$ & $2.22 \pm 0.41^{\mathrm{c}}$ \\
200 & $2.6 \pm 1.47^{\mathrm{abc}}$ & $3.04 \pm 0.42^{\mathrm{abc}}$ & $4.02 \pm 0.62^{\mathrm{a}}$ & $1.74 \pm 0.4^{\mathrm{c}}$ \\
300 & $1.64 \pm 0.61^{\mathrm{c}}$ & $2.14 \pm 0.22^{\mathrm{bc}}$ & $2.2 \pm 1.15^{\mathrm{bc}}$ & $1.6 \pm 0.49^{\mathrm{c}}$ \\
\hline
\end{tabular}

Note: the numbers with the same notation in the Tukey test are not significantly different $(\mathrm{P}<0.05)$

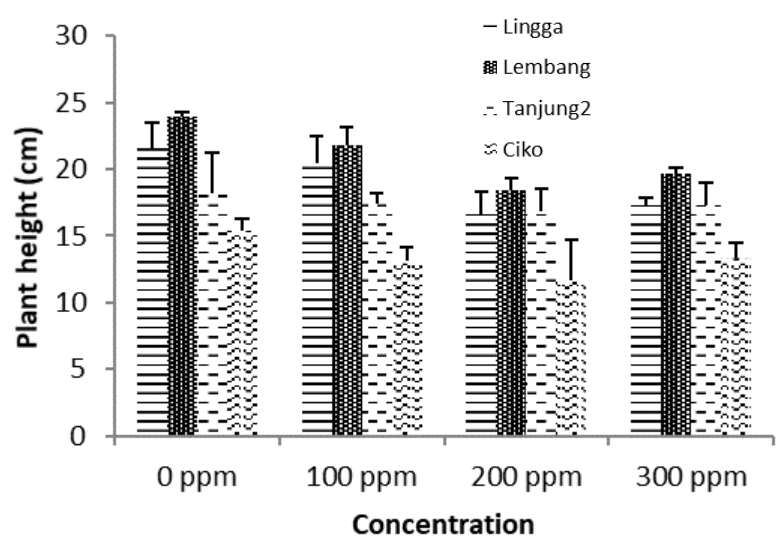

Figure 4. Response of Capsicum varieties on plant height under $\mathrm{Al}$ stress treatment at 73 days after planting (DAP)

Plants have developed different mechanisms to cope with heavy metal stress (Jadid et al. 2017; Manara, 2012). Heavy metal stress might induce program cell death (PCD). Consequently, some plant organ growth will be inhibited (Huang et al. 2014). Another study also demonstrated that $\mathrm{AlCl} 3$ inhibited the growth of peanut roots along with the increase of $\mathrm{Al}$ stress concentration and exposure time. It had been also described that $\mathrm{Al}$ stress-induced reactive oxygen species (ROS) production along with the increase in $\mathrm{Al}$ exposure. Therefore, PCD might be a consequence of massive ROS production within plant cells (Huang et al. 2014). The formation of ROS had been reported occurred in protoplast after $4 \mathrm{~h}$ of $\mathrm{Al}$ exposure. This free radical is generated from the mitochondria and it increases along with the $\mathrm{Al}$ induction (Huang et al. 2014).

\section{ACKNOWLEDGEMENTS}

The authors greatly acknowledge the Ministry of Research and Technology of the Republic of Indonesia that finances this study through Master Research (Grant No. 1410/PKS/ITS/2020). We also thank the member of Laboratory of Plant Bioscience and Plant Technology, Department of Biology, Institut Teknologi Sepuluh Nopember, Surabaya-Indonesia who has supported this study.

\section{REFERENCES}

Acharya L, Mukherjee AK, Panda PC. 2004. Genome relationship among nine species of Millettieae (Leguminosae: Papilionoideae) based on random amplified polymorphic DNA (RAPD). Z Naturforsch 59: 868-873. DOI: 10.1515/znc-2004-11-1217

Animasaun DA, Morakinyo JA, Krishnamurthy R. 2015. Assessment of genetic diversity in accessions of pearl millet (Pennisetum glaucum) and Napier grass (Pennisetum purpureum). Iran J Genet Plant Breed 4 (1): 25-35.

Balitsa. 2018. Varietas Cabai. Balai Penelitian Tanaman Sayuran, Lembang, Bandung. [Indonesian]

Das A, Gaur M, Barik DP, Subudhi E. 2017. Genetic diversity analysis of 60 ginger germplasm core accessions using ISSR and SSR markers. $\begin{array}{lllll}\text { Plant } & \text { Biosyst } & 151 & \text { (5): } & 822-832 .\end{array}$ 10.1080/11263504.2016.1211197

Dikshita N, Sivarajb N. 2015. Analysis of agromorphological diversity and oil content in Indian linseed germplasm. Grasas y Aceites 66 (1): e060. DOI: 10.3989/gya.0689141

Dogic S, Dzubur N, Karalija E, Paric A. 2017. Biochemical responses of basil to aluminium and cadmium stresses. Acta Agriculturae Serbica 17 (43): 57-651. DOI: 10.5937/AASer1743057D

Ganguly S, Praveen KP, Para PA. 2017. Medicinal properties of chilli pepper in human diet. ARC J Public Health Commun Med 2 (1): 6-7. DOI: $10.20431 / 2456-0596.0201002$

Handayanto E, Muddarisna N, Fiqri A. 2017. Pengelolaan Kesuburan Tanah. Penerbit Universitas Brawijaya Press, Malang. [Indonesian]

He H, Li Y, He L. 2019. Review: Aluminium toxicity and tolerance in Solanaceae plants. S Afr J Bot 123: 23-29. DOI: 10.1016/j.sajb.2019.02.008

Hildebrand E, DC. Torney, RP. Wagner. 1992. Informativeness of polymorphic DNA markers. Los Alamos Science 20: 100-102.

Hoffman PG, Lego MC, Galetto WG. 1983. Separation and quantitation of red pepper major heat principles by reverse-phase high-pressure liquid chromatography. J Agric Food Chem 31: 1326-1330. DOI: 10.1021/jf00120a044

Huang WJ, Oo TL, He HY, Wang AQ, Zhan J, Li QZ, Wei SQ, He LF. 2014. Aluminum induces rapidly mitochondria-dependent programmed cell death in Al-sensitive peanut root tips. Bot Stud 55 (67). DOI: 10.1186/s40529-014-0067-1

Ibarra-Torres P, Valadez E, Grajales, Campos R, Flores J. 2015. Inter-and intraspecific differentiation of Capsicum annuиm and Capsicum pubescens using ISSR and SSR markers. Scientia Horticulturae 181: 137-146. DOI: 10.1016/j.scienta.2014.10.054

Igwe DO, Afiukwa CA, Ubi BE, Ogbu KI, Ojuederie OB, Ude GE. 2017. Assessment of genetic diversity in Vigna unguiculata L. (Walp) accessions using inter-simple sequence repeat (ISSR) and start codon targeted (SCoT) polymorphic markers. BMC Genet 18: 1-13. DOI: 10.1186/s12863-017-0567-6

Jadid N, Mardika RK, Nurhidayati T, Irawan MI. 2016. Reverse Transcription-PCR analysis of geranylgeranyl diphosphate synthase (JcGGPPS) in Jatropha curcas L. and in silico analysis of Casbene Synthase (JcCS) among Euphorbiaceae. AIP Conf Proc 1744: 020042. DOI: $10.1063 / 1.4953516$

Jadid N, Maziyah R, Nurcahyani DW, Mubarokah NR. 2017. Growth and physiological responses of some Capsicum frutescens varieties to copper stress. AIP Conf Proc 1854: 020018. DOI: 10.1063/1.4985409

Jadid N, Estiasih E, Saputro TB, Purwani KI, Hidayati D, Permatasari EV, Kurniawan WD. 2018. Expression pattern of drought-responsive genes in burley tobacco under in vitro water deficit. J Physics 1040: 012004. DOI: 10.1088/1742-6596/1040/1/012004

Jadid N, Mardika RK, Purwani KI, Permatasari EV, Prasetyowati I, Irawan MI. 2018. Transcription profile data of phorbol esters biosynthetic genes during developmental stages in Jatropha curcas. Data Brief 18: 700-705. DOI: 10.1016/j.dib.2018.03.061 
Karimaei M, Poozesh V. 2016. Effects of aluminum toxicity on plant height, total chlorophyll $(\mathrm{Chl} \mathrm{A}+\mathrm{B})$, potassium and calcium contents in spinach (Spinacia oleracea L.). Int J Farm Allied Sci 5 (2): 76-82.

Khan BA, Leskovar DI. 2006. Cultivar and plant arrangement effects on yield and fruit quality of bell pepper. Hort Sci 4 (7): 1565-1570. DOI: 10.21273/HORTSCI.41.7.1565

Kuepper H, Kupper F, Spiller M. 1998. In situ detection of heavy metal substituted chlorophyll in water plants. Photosynthesis Res 58 (2): 123-133. DOI: 10.1023/A:1006132608181

Manara A. 2012. Plant response to heavy metal Toxicity. In: Furini A (eds) Plants and Heavy Metals. Springer Briefs in Molecular Science. Springer, Dordrecht. DOI: 10.1007/978-94-007-4441-7_2

Mandal A, Datta AK, Datta S, Gupta S. 2013. Genetic assessment of eigh Corchorus spp. (Tiliaceae) using RAPD and ISSR markers. Nucleus 56: 23-30. DOI: 10.1007/s13237-013-0076-6

Mantovanini J, Silva R, Silva L, Santos T, Maria D, Zingaretti M. 2019. Root system development and proline accumulation in sugarcane leaves under aluminum ( $\mathrm{Al}^{3+)}$ stress. Aust J Crop Sci 13 (2): 208-213. DOI: $10.21475 /$ ajcs.19.13.02.p1198

Mateescu G, Zhang Z, Tsai k, Phavaphutanpn J, Wurster B, Lust G. Quaas R, Murphy K, Acland M, Todhunter R. 2005 Analysis of allele fidelity, polymorphic information content, and density of microsatellites in a genome-wide screening for hip dysplasia in a crossbreed pedigree. J Heredity 96 (7): 847-853. DOI: 10.1093/jhered/esi109

McCauley A. 2011. Plant Nutrient Functions and Deficiency Nutrient Management. Montana State University, USA.

Mehrotra S, Goyal V. 2014. Review: Repetitive sequences in plant nuclear DNA: Types, distribution, evolution and function. Genomics Proteomics Bioinformatics 12: 164-171. DOI 10.1016/j.gpb.2014.07.003

Moustaka J, Ouzounidou G, Baycu G, Moustakas M. 2016. Aluminum resistance in wheat involves maintenance of leaf $\mathrm{Ca}^{2+}$ and $\mathrm{Mg}^{2+}$ content, decreased lipid peroxidation and $\mathrm{Al}$ content, and low photosystem II excitation pressure. Biometals 29: 611-623. DOI 10.1007/s10534-016-9938-0

Monfared MA, Samsampour D, Sharifi-Sirchi GR, Sadeghi F. 2018. Assessment of genetic diversity in Salvadora persica L. based on inter simple sequence repeat (ISSR) genetic marker. J Genet Eng Biotechnol 16 (2): 661-667. DOI: 10.1016/j.jgeb.2018.04.005

Mulyani A, Hikmatullah, Subagyo H. 2004. Karakteristik dan potens tanah masam lahan kering di Indonesia. Prosiding Simposium Nasional Pendayagunaan Tanah Masam. Pusat Penelitian dan Pengembangan Tanah dan Agroklimat, Bogor. Indonesia. [Indonesian]

Ng WL, Onishi Y, Inomata N, Teshima KM, Chan HT, Baba S, Changtragoon S, Siregar IZ, Szmidt AE. 2015. Closely related and sympatric but not all the same: genetic variation of Indo-West Pacific Rhizophora mangroves across the Malay Peninsula. Conserv Genet 16: 137-150. DOI: 10.1007/s10592-014-0647-3

Oh WM, Roy SK, Kamal AHM, Cho K, Cho S-W, Park C-S, Choi J-S, Komatsu S, Woo S-H. 2013. Proteome analysis of roots of wheat seedlings under aluminum stress. Mol Biol Rep 41 (2): 671-681. DOI: $10.1007 / \mathrm{s} 11033-013-2905-8$

Olatunji L, Afolayan J. 2019. Evaluation of genetic relationship among varieties of Capsicum annuum $\mathrm{L}$. and Capsicum frutescens $\mathrm{L}$. in West Africa using ISSR markers. Heliyon 5: e01700. DOI: 10.1016/j.heliyon.2019.e01700

Panda SK, Baluska F. 2015. Aluminium Stress Adaptation in Plants. Springer, Nederland. DOI: 10.1007/978-3-319-19968-9

Qamar W, Khan MR, Arafah A. 2017. Optimization of conditions to extract high-quality DNA for PCR analysis from whole blood using SDS-proteinase K method. Saudi J Biol Sci 24 (7): 1465-1469. DOI: 10.1016/j.sjbs.2016.09.016

Raharjo B, Suprihadi, Agustina DK. 2007. Pelarutan fosfat anorganik oleh kultur campur jamur pelarut fosfat secara in vitro. Jurnal Sains \& Matematika 15 (2): 45-54. [Indonesian]

Rana M, Sharma R, Sharma P, Bhardwaj SV, Sharma M. 2014. Estimation of genetic diversity in Capsicum anпиит L. germplasm using PCR-based molecular markers. Natl Acad Sci Lett 37: 295-30. DOI: $10.1007 / \mathrm{s} 40009-014-0236-5$

Ray A, Jena S, Haldar T, Sahoo A, Kar B, Patnaik J, Ghosh B, Panda PC, Mahapatra N, Nayak. 2019. Population genetic structure and diversity analysis in Hedychium coronarium populations using morphological, phytochemical and molecular markers. Ind Crop Prod 132: 118-133. DOI: $10.1016 /$ j.indcrop.2019.02.015

Rukmana R. 2002. Usaha Tani Cabai Rawit. Kanisius, Yogyakarta. Indonesia. [Indonesian]

Setiadi. 2006. Bertanam Cabai. Penebar Swadaya, Jakarta. [Indonesian]

Shanmugam A, Sudharsan S, Seedevi P, Ramasamy P, Subhapradha N, Vairamani S. 2012. Heavy metal accumulation in seaweeds and seagrasses along southeast coast of India. J Chem Pharmaceut Res 4 (9): 4240-4244

Subagyo H, Widjaja A. 1998. Peluang dan kendala pembangunan lahan rawa untuk pengembangan pertanian di Indonesia. dalam Prosiding Pertemuan Pembahasan dan Komunikasi Hasil Penelitian Tanah dan Agroklimat: Makalah Utama. Bogor, 10-12 Februari 1998. Pusat Penelitian Tanah dan Agroklimat, Bogor. Indonesian. [Indonesian]

Sudupak MA. 2004. Inter and intra-species inter simple sequence repeat (ISSR) variations in the genus Cicer. Eucalypta J 135: 229-238. DOI: 10.1023/B:EUPH.0000014938.02019.f3

Sun QB, Li LF, Li Y, Wu GJ, Ge XJ. 2008. SSR and AFLP markers reveal low genetic diversity in the biofuel plant Jatropha curcas in China. Crop Sci 48: 1865-1871. DOI: 10.2135/cropsci2008.02.0074

Supena N, Soegianto A, Soetopo L. 2014. Response of oil palm varieties to aluminum stress. J Trop Life Sci (1): 51-60.

Xing C, Tian Y, Guan F, Meng F. 2015. Evaluation of genetic diversity in Amygdalus mira (Koehne) Ricker using SSR and ISSR markers. Plant Syst Evol 301 (3): 1055-1064. DOI: 10.1007/s00606-014-1136-3

Yagi M, Shirasawa K, Waki T, Kume T, Isobe S, Tanase K, Yamaguchi H. 2017. Construction of an SSR and RAD marker-based genetic linkage map for carnation (Dianthus caryophyllus L.). Plant Mol Biol Rep 35: 110-117. DOI: 10.1007/s11105-016-1010-2 